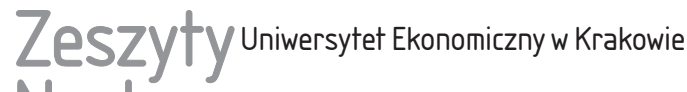 Naukowe
}

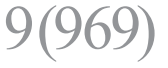

ISSN 1898-6447

Zesz. Nauk. UEK, 2017; 9 (969): 33-48 DOI: 10.15678/ZNUEK.2017.0969.0903

\author{
Marcin Kawalec
}

\section{Wpływ kryzysu finansowego na możliwość wprowadzenia federalizmu fiskalnego w strefie euro}

\section{Streszczenie}

Unia gospodarcza i walutowa przechodzi kryzys wywołany czynnikami wewnętrznymi oraz zewnętrznymi. Problemy, jakie pojawiły się w wyniku szoku makroekonomicznego, uwidoczniły błędy konstrukcyjne unii walutowej. Celem artykułu jest określenie, czy możliwa jest stabilna unia monetarna bez unii fiskalnej, oraz tego, jak kryzys finansowy wpłynął na możliwość wprowadzenia federalizmu fiskalnego w strefie euro. Omówiono zagadnienia dotyczące istnienia strefy euro w warunkach kryzysu gospodarczego, przedstawiono także najważniejsze problemy związane z funkcjonowaniem unii walutowej i zarządzaniem kryzysem finansowym w Unii Europejskiej. Przeprowadzono analizę rozwiązań instytucjonalnych wprowadzanych w wyniku ujawniania się problemów w osiągnięciu konwergencji nominalnej podczas tworzenia strefy euro oraz powstawania nierównowagi budżetowej w związku ze światowym kryzysem finansowym. Rozwiązania te mogą kiedyś stanowić podstawę do utworzenia unii fiskalnej w ramach strefy euro.

Słowa kluczowe: Unia Europejska, strefa euro, unia monetarna, unia fiskalna.

Klasyfikacja JEL: E44, E62, F15, F36, F45.

Marcin Kawalec, Uniwersytet Ekonomiczny w Krakowie, Studia Doktoranckie, Wydział Ekonomii i Stosunków Międzynarodowych, ul. Rakowicka 27, 31-510 Kraków, e-mail: marcin. kawalec.uek@gmail.com 


\section{Wprowadzenie}

Kryzys gospodarczy, jaki dotknął w 2011 r. unię walutową w Europie, miał swoje źródło w problemach na rynku kredytów hipotecznych w Stanach Zjednoczonych. Rozpoczęły się one w 2007 r., początek kryzysu łączony jest jednak z upadkiem banku Lehman Brothers we wrześniu 2008 r. Powodem zaistniałych problemów było udzielanie kredytów hipotecznych podmiotom o niskiej wiarygodności kredytowej (subprime). Stawianie niewygórowanych wymagań doprowadziło do utworzenia się bańki spekulacyjnej na amerykańskim rynku nieruchomości [Götz 2012, s. 14-15].

Ze względu na silne zintegrowanie rynków finansowych amerykański kryzys objął również obszar Europy, wywołując pogorszenie się koniunktury gospodarczej oraz recesję w strefie euro. Zadłużenie publiczne, czym ratowano gospodarkę, wzrosło do poziomu budzącego zaniepokojenie na rynkach finansowych. Punktem kulminacyjnym europejskiego kryzysu było jednak ujawnienie przez Grecję w październiku 2008 r. realnego długu i deficytu, które w rzeczywistości były o wiele większe niż oficjalnie podawano w statystykach. Sytuacja ta całkowicie zmieniła podejście na rynkach zarówno do Grecji, jak i do innych nadmiernie zadłużonych państw strefy euro [Gajewski 2013, s. 6].

Wpływ kryzysu na amerykańskim rynku kredytów hipotecznych na sytuację w Europie i w strefie euro ma charakter zewnętrzny. Na problemy unii walutowej oddziałują także czynniki wewnętrzne, wynikające z różnych aspektów funkcjonowania Unii Europejskiej. Kryzys gospodarczy uwidocznił wady konstrukcyjne unii gospodarczej i walutowej w strefie euro. Można przypuszczać, że to właśnie błędy w jej strukturze przyczyniły się do problemów, jakich obecnie doświadcza unia [Götz 2012, s. 65].

Jak zauważa K. Mitręga-Niestrój [2014, s. 111], UE nie dysponowała mechanizmami zarządzania kryzysem finansowym. Istniały jedynie dwu- i wielostronne porozumienia, opierające się na dobrowolnej współpracy, pozbawione jednak wiążącej mocy prawnej. Być może, na podstawie doświadczeń sprzed kryzysu, zbyt optymistycznie podchodzono do dalszego przebiegu integracji. Nie opracowano mechanizmu zarządzania kryzysowego, państwa podjęły doraźne działania za pomocą środków publicznych, w niespotykanej dotąd skali. Było to więc „zarządzanie przez dofinansowanie”, które skutkowało nadmierną nierównowagą budżetową w państwach UE [The European... 2011, s. 1].

Celem artykułu jest określenie, czy możliwa jest stabilna unia walutowa bez unii fiskalnej oraz jak kryzys finansowy wpłynął na możliwość wprowadzenia federalizmu fiskalnego w strefie euro. Omówiono zagadnienie funkcjonowania strefy euro w warunkach kryzysu gospodarczego oraz przedstawiono najważniejsze problemy związane z unią walutową i zarządzaniem kryzysem finansowym 
w UE. Przeprowadzono także analizę rozwiązań instytucjonalnych wprowadzanych w związku z pojawiającymi się problemami w osiągnięciu konwergencji nominalnej przy tworzeniu strefy euro oraz nierównowagą budżetową państw spowodowaną światowym kryzysem finansowym. Rozwiązania te mogą stać się w przyszłości podstawą do utworzenia unii fiskalnej w ramach Unii Gospodarczej i Walutowej (UGiW).

\section{Funkcjonowanie strefy euro w warunkach kryzysu gospodarczego}

Charakterystyczną cechą makroekonomicznej polityki stabilizacyjnej państwa jest wypracowanie dwóch niezależnych, lecz uzupełniających się mechanizmów: polityki fiskalnej, prowadzonej przez rząd, oraz polityki pieniężnej, koordynowanej przez krajowy bank centralny. Odpowiednie użycie narzędzi tych dwóch mechanizmów pozwala na wyprowadzenie gospodarki ze stanów nierównowagi w wypadku wystąpienia szoków makroekonomicznych [Kawalec 2014, s. 57].

UGiW miała być projektem pozwalającym na zniesienie kolejnych barier w handlu zagranicznym oraz umożliwiającym wzrost i rozwój gospodarczy. Warto jednak przytoczyć słowa byłego prezesa Europejskiego Banku Inwestycyjnego P. Maystadta [Pielach 2012], według którego ,wielu negocjujących traktat z Maastricht miało polityczną schizofrenię". Ową opinię tłumaczył tym, że decydenci, podejmując się utworzenia unii walutowej, a więc mechanizmu silnie integrującego, oczekiwali równocześnie zachowania suwerenności w sprawach budżetu i gospodarki. Wielu innych specjalistów z dziedziny ekonomii także dostrzegało rażące błędy popełnione podczas tworzenia UGiW, a uwagi formułowało jeszcze przed podpisaniem traktatu z Maastricht (zob. [Kawalec 2014, s. 57]).

Europejscy decydenci, dążąc do utworzenia UGiW jako kolejnego po strefie wolnego handlu, unii celnej i wspólnym rynku etapu w procesie integracji, zastosowali pewnego rodzaju półśrodki. Unifikacja polityki monetarnej prowadzonej przez Europejski Bank Centralny (EBC) oraz określenie kryteriów konwergencji nominalnej (zarówno stabilności polityki pieniężnej: stóp procentowych oraz inflacji, jak i stabilności polityki budżetowej: deficytu oraz długu publicznego) to jedyne podstawy, na jakich miało się opierać sprawne funkcjonowanie unii walutowej. Praktycznym mechanizmem kontroli polityki budżetowej państw członkowskich strefy euro miał być wprowadzony pakt stabilności i wzrostu, wymuszający na członkach eurostrefy dyscyplinę budżetową [Gajda-Kantorowska i Tarnawska 2009, s. 14-26].

Do jednej z największych wad konstrukcyjnych unii walutowej P. Maystadt [Pielach 2012] zalicza rozwiązania przyjęte wraz z wprowadzeniem paktu stabil- 
ności i wzrostu: oparcie się wyłącznie na dyscyplinie budżetowej powoduje pominięcie innych elementów gospodarki. Błędnie zakładano, że osiągnięcie równowagi budżetowej pozwoli na zniwelowanie wszelkich innych nierówności. Pakt stabilności i wzrostu nie wprowadzał rozróżnienia wydatków konsumpcyjnych i inwestycyjnych, co powinno być obowiązującą zasadą budżetową. Nie opracowano również skutecznego mechanizmu postępowania na wypadek problemów z wypłacalnością lub utratą płynności finansowej. Nie wprowadzono także odpowiedniego systemu kontroli bankowej (zob. [Kawalec 2014, s. 58]).

Upatrywanie przyczyn kryzysu wyłącznie w problemach dotyczących finansów publicznych jest podejściem błędnym i niekompletnym. Państwa takie jak Irlandia czy Hiszpania przed kryzysem posiadały porównywalnie stabilne finanse publiczne, a Niemcy, przekraczające dopuszczalne normy ustanowione na mocy traktatu z Maastricht, radziły sobie podczas kryzysu bardzo dobrze. Istotna jest w tym wypadku także kwestia współzależności trzech celów, co w dużej mierze wyjaśnia charakter niespójności w budowie strefy euro. Zgodnie z koncepcją tryptyku celów nie do pogodzenia (trójkąta niemożliwości) J. Pisani-Ferry’ego [2012, s. 4-9] nie powinny jednocześnie występować następujące sytuacje (ich współwystępowanie jest powodem niespójności w funkcjonowaniu strefy euro):

1) zadłużanie się państw w walucie, której nie emitują i nad którą nie mają rzeczywistej kontroli, czyli tzw. grzech pierwotny unii monetarnej,

2) zakazanie EBC udzielania pomocy finansowej - bank strefy euro nie może nabywać papierów skarbowych państw członkowskich na rynku pierwotnym (w gospodarkach krajowych takie działanie jest często praktykowane jako mechanizm stabilizujący),

3) współzależność bankowo-publiczna, polegająca na „udomowieniu” portfeli banków, utrzymujących w swoich aktywach przede wszystkim papiery skarbowe własnych rządów, co w wypadku zaistnienia kryzysu wpływa na wypłacalność banków i poziom ich płynności finansowej.

Do wewnętrznych źródeł kryzysu strefy euro należy również zaliczyć jej specyficzną konstrukcję, która umożliwiała jej poszczególnym członkom kreowanie deficytów budżetowych oraz przyjmowanie zobowiązań na ich pokrycie przy wsparciu EBC jako podmiotu nabywającego ich obligacje. Według P. Bagusa [2010, s. 86-90] powodem kryzysu UGiW było uleganie przez biedniejsze państwa pokusie nadużywania tego mechanizmu (skupowania długu przez EBC). Doprowadziło to do zaistnienia tzw. zjawiska tragedii wspólnego pastwiska (tragedy of the commons), czyli krótkookresowego zysku jednego państwa kosztem innych - koszty greckich deficytów zostały niejako przerzucone na pozostałe kraje UGiW. EBC, skupując greckie papiery dłużne, zmonetaryzował i ukrył problem. Rząd Grecji wydał pozyskane pieniądze na ustabilizowanie poparcia społecznego dla reform, wzrost cen w Grecji wpłynął zaś na pozostałe kraje strefy euro. 
Konsekwencją tego był odczuwany przez obywateli UE szybszy wzrost kosztów życia niż dochodów. Sytuacja w Grecji ze względu na długotrwały napływ siły nabywczej euro została uratowana przez pozostałe państwa UGiW [Bagus 2010, s. 70-86].

Zdaniem K. Bieguna [2003, s. 1-10] strefa euro jest raczej pewną formą współpracy międzynarodowej polegającej na przyjęciu sztywnych kursów walutowych niż klasyczną unią monetarną. Dopóki gospodarka światowa była w dobrej kondycji, wspólna waluta europejska funkcjonowała bez większych problemów. Kryzys uwidocznił niestabilność UGiW, nieposiadającej narzędzi stabilizowania wewnętrznych rozbieżności. Obecna UGiW nie spełnia zatem kryteriów optymalnych obszarów walutowych, a co za tym idzie, w wypadku asymetrycznych szoków makroekonomicznych nie gwarantuje mobilności siły roboczej ani kapitału, np. w formie transferów wyrównujących [de Grauwe 2003, s. 69-87; Götz 2012, s. 66-67].

Kryzys w strefie euro jest wywołany nie tylko wpływem czynników zewnętrznych, jak szoki makroekonomiczne, czy wad konstrukcyjnych unii walutowej. Jak zauważa M. Götz [2012, s. 73], do istotnych przyczyn problemów dotyczących wspólnej waluty należy także zaliczyć ,,czynniki miękkie”, takie jak: brak kultury fiskalnej, etosu pracy, dyscypliny finansowej czy skłonności do oszczędzania. Przyjmując taką perspektywę, autor odwołuje się więc do narodowych cech państw członkowskich. Kwestie te odnoszą się także do wspomnianej pokusy nadużycia.

\section{Charakterystyka problemów strefy euro}

Problemy strefy euro można rozpatrywać w różnych kontekstach. Z uwagi na cel niniejszej publikacji należy zwrócić szczególną uwagę na kwestie związane z kryzysem ekonomiczno-politycznym w ramach unii (wynikającym m.in. z braku jednomyślności co do sposobu wyjścia z kryzysu finansowego i przeciwdziałania nowym szokom), a także z konwergencją makroekonomiczną, zarówno w jej ujęciu realnym, a więc odnoszącym się do podobieństwa gospodarek, jak i nominalnym, związanym z brakiem dyscypliny finansowej.

Za przyczynę kryzysu ekonomiczno-politycznego w strefie euro można uznać jej mało ekonomiczny wymiar. Pogląd ten pokrywa się z opinią P. Maystadta (zob. [Kawalec 2014, s. 61]), dla którego kryzys ten jest oczywiście kryzysem ekonomicznym, ponieważ ujawnia ogromne problemy gospodarek, ich olbrzymie deficyty i zadłużenie. Są one skutkiem rozrośniętych sektorów finansowych państw dobrobytu, które nie mają przełożenia na realną gospodarkę, oraz niepokojąco małej konkurencyjności wielu państw. Brak filara fiskalnego oraz niski 
stopień konwergencji gospodarek może także świadczyć o tym, że koncepcja utworzenia unii walutowej była projektem politycznym (zob. [Götz 2012, s. 81-82]).

Zdaniem M. Götz [2012, s. 85] w kontekście polityki należy rozpatrywać nie tylko przyczyny kryzysu (przystąpienie do strefy euro Belgii, Holandii i Włoch bez spełnionych warunków członkostwa) i jego przebieg (nieprzestrzeganie przez Francję oraz Niemcy przepisów ustanowionych na mocy paktu stabilności i wzrostu), polityczny charakter mają też wszelkie decyzje podejmowane w celu jego przezwyciężenia. Uporanie się z impasem w strefie euro wymaga podjęcia śmiałych decyzji politycznych, dotyczących nie tylko działań doraźnych, lecz również długofalowych. Konieczne jest zatem dojście do konsensusu pomimo ograniczeń wynikających z cykli wyborczych, zobowiązań wobec wyborców oraz prób uspokojenia rynków finansowych. Decyzje te powinny więc prowadzić do jednego z dwóch rezultatów: trwałego wyeliminowania wad konstrukcyjnych strefy euro bądź rozwiązania unii walutowej.

Przypadek kontrolowanego rozwiązania strefy euro analizują S. Kawalec i E. Pytlarczyk [2016, s. 199-204]. W publikacji poświęconej zagadnieniom dotyczącym kryzysu unii walutowej uzasadniają, że taki zabieg ma uchronić UE oraz wspólny rynek przed zbyt daleko posuniętymi ruchami dezintegracyjnymi. Jak zauważają, istotne jest to, aby rozwiązanie strefy euro zostało dokonane przez proeuropejskich i prorynkowych przedstawicieli państw UE.

Unię Europejską, a w szczególności jej unię monetarną, przyrównuje się często do Stanów Zjednoczonych. Z porównania tych dwóch obszarów walutowych wynika kilka wniosków: poszczególne stany w Stanach Zjednoczonych są mniej zróżnicowane niż państwa członkowskie strefy euro, migracja i mobilność siły roboczej pomiędzy stanami są znacznie większe niż w eurostrefie, Stany Zjednoczone są bardziej zintegrowanym rynkiem niż strefa euro, a automatyczne stabilizatory finansowe $\mathrm{w}$ formie przepływów finansowych pomiędzy stanami odgrywają ważną rolę i nie mają odpowiedników w europejskiej unii walutowej. Budżet strefy euro (ok. 1,5\% PKB) jest także o wiele mniejszy niż budżet amerykański (ok. 25\% PKB) [Dadush, Wyne i Ali 2012].

Powyższe dane potwierdzają, że eurostrefa nie spełnia podstawowych warunków określonych w klasycznej teorii optymalnych obszarów walutowych. Biorąc pod uwagę sekwencję integracji B. Balassy [1961, s. 173-185], UE udało się dotrzeć do jej końcowych etapów. Jak uważa M. Götz [2012, s. 66], perturbacje w gospodarce światowej obnażyły wszelkie słabości wspólnej waluty. Państwa członkowskie różnią się polityką budżetową (jej rolą, odmienne są też automatyczne stabilizatory koniunktury) i monetarną (różne są systemy bankowe, stopy procentowe są niedopasowane do potrzeb poszczególnych gospodarek), są również zróżnicowane pod względem makroekonomicznym (odmienne cykle koniunkturalne, struktura gospodarek). To właśnie brak wewnętrznej konwergencji, zauwa- 
żalny w wielu obszarach, jest uważany za praprzyczynę kryzysu w eurostrefie. W innej sytuacji problemy Grecji czy innych państw PIIGS (Portugal, Italy, Island, Greece, Spain) byłyby o wiele prostsze do rozwiązania [Kawalec 2014, s. 60].

A. Tornell i F. Westermann [2012] zwracają uwagę na to, że oprócz wad konstrukcyjnych unii walutowej (ograniczenia jej wyłącznie do unii monetarnej) i słabego mandatu EBC przyczyną kryzysu było również nieodpowiedzialne zachowanie władz poszczególnych państw. Odnosi się to do wspomnianej już pokusy nadużycia. Doprowadziło to również do wystąpienia tzw. zjawiska wspólnego pastwiska. W kontekście kryzysu oznacza to, że krajowe podmioty nadzorujące system bankowy, podejmując działania ochronne wobec innych podmiotów krajowych, akceptują nadużycia, mimo że tracą na tym inni członkowie unii walutowej [Götz 2012, s. 73].

W Grecji przejawem nieodpowiedzialnej polityki było dopuszczenie do sytuacji, w której wydatki przestały mieć przełożenie na realne dochody. Doprowadziło to do wzrostu deficytu, pokrywanego z pożyczek zaciąganych na krajowym bądź zagranicznym rynku finansowym, a w konsekwencji do zwiększenia zadłużenia. Prowadzenie takiej polityki wymagało zaoferowania odpowiednio wyższych stóp procentowych, które zachęciłyby inwestorów do finansowania wydatków państwa greckiego. Takie podejście skutkowało wzrostem ciężaru długu (kosztów obsługi) i wymagało jego rolowania, a więc zaciągania kolejnych pożyczek na sfinansowanie bieżących wydatków oraz spłatę wcześniejszego zadłużenia. Spowodowało to także wzrost cen i spadek konkurencyjności krajowych dóbr, a także wpłynęło na pogorszenie wyników na rachunku obrotów bieżących [Götz 2012, s. 73-74].

\section{Elementy federalizmu fiskalnego w strefie euro}

Unia Europejska, wdrażając plan utworzenia jednolitego obszaru walutowego, podjęła decyzję, aby kompetencje w zakresie polityki monetarnej i walutowej państw strefy euro realizowane były na szczeblu ponadnarodowym. Równocześnie pozostawiono państwom suwerenność w zakresie prowadzenia polityki fiskalnej.

Jak zauważa H. Tendera-Właszczuk [2014, s. 65], tak skonstruowana strefa euro funkcjonowała bez większych problemów do czasu nastania kryzysu, który uwidocznił największe wady istniejącego systemu. Podjęto zatem próby wprowadzenia instrumentów kontroli i koordynacji polityki gospodarczej państw członkowskich, ukierunkowanych głównie na stabilizację fiskalną. Głównym celem zastosowania ich miało być wczesne wykrywanie i eliminowanie zagrożeń funkcjonowania i stabilności unii walutowej.

Unia walutowa ma wadliwą konstrukcję. Klasyczna teoria optymalnych obszarów walutowych, zaproponowana przez R. Mundella [1961, s. 657-665], 
odnosi się do sytuacji, w której konieczne są alternatywne wobec kursu walutowego i niezależności banku centralnego mechanizmy dostosowawcze w wypadku wystąpienia asymetrycznych szoków makroekonomicznych. Z kolei R. McKinnon [1963, s. 717-725] oraz P. Kenen [1969, s. 41-60] koncentrują się na przeciwdziałaniu asymetrii w cyklach koniunkturalnych oraz zmniejszeniu prawdopodobieństwa ich powstania. Według nich istotą problemu jest więc niezależna krajowa polityka fiskalna i brak autonomii w polityce monetarnej na poziomie krajowym.

$\mathrm{Z}$ analizy teorii optymalnych obszarów walutowych wynika, że przy spełnieniu warunków optymalności, czyli realizacji kryteriów realnej konwergencji makroekonomicznej, obecna forma unii walutowej (strefa euro) nie wymagałaby wprowadzenia zmian, a procesy dostosowawcze mogłyby zachodzić. Unia walutowa w małym jednak stopniu spełnia kryteria konwergencji realnej (m.in. zróżnicowania struktury produkcji, zbieżności cykli koniunkturalnych czy elastyczności rynku pracy), a więc nie jest obszarem optymalnym. Nawet w wypadku konieczności utworzenia unii walutowej R. Mundell [1961, s. 657-665] zakłada obligatoryjność zapewnienia mobilności kapitału, którą rozumie jako federalizm fiskalny, wspólny budżet mogący pełnić funkcję stabilizacyjną gospodarki. Opisuje więc sytuację, w jakiej znajduje się strefa euro.

Można dostrzec pewne próby przełamania niechęci wobec wprowadzenia niezależnej polityki fiskalnej na poziom ponadnarodowy. Jest to często powiązane z działaniami stabilizacyjnymi i antykryzysowymi skoncentrowanymi na niwelowaniu bieżących problemów i przeciwdziałaniu wystąpieniu ich w przyszłości. W miarę rozwoju UGiW w coraz szerszym zakresie wprowadzana jest kontrola oraz unifikacja polityki fiskalnej.

Spełnienie kryteriów konwergencji nominalnej, określonych pierwotnie w traktacie z Maastricht, miało umożliwić państwom Unii przyjęcie wspólnej waluty. Co do zasady, w okresie poprzedzającym członkostwo w strefie euro państwa dążyły do spełnienia tych wymogów. Zdaniem H. Tendery-Właszczuk [2014, s. 66] kryteria te okazały się skuteczne tylko w pewnym stopniu, ponieważ w niektórych krajach po przystąpieniu do strefy euro ponownie doszło do wystąpienia nierównowagi w zakresie konwergencji nominalnej.

Wprowadzenie wspólnej waluty było początkowo planowane na 1997 r. Z raportu dotyczącego konwergencji nominalnej przedstawionego w 1996 r. przez Europejski Instytut Walutowy wynikało jednak, że zdecydowana większość państw nie spełniła w wystarczającym zakresie wymaganych kryteriów konwergencji: Grecja, Hiszpania, Portugalia i Włochy nie wykazały zbieżności z zakładanymi rezultatami w żadnym z badanych obszarów [Progress... 1996]. Słabe wyniki konwergencji w latach 1995 i 1996 zmusiły państwa UE do przedłużenia realizacji trzeciego etapu integracji w ramach UGiW do 1999 r. [Kołodziejczyk 2000, s. 107-109]. 
$\mathrm{Z}$ uwagi na trudności z zachowaniem dyscypliny finansowej przed przyjęciem wspólnej waluty oraz ryzyko nieprzestrzegania tej dyscypliny po przyjęciu euro konieczne było wprowadzenie mechanizmu kontroli już na samym początku tworzenia unii walutowej. Pakt stabilności i wzrostu, przyjęty na szczycie Rady Europejskiej w Amsterdamie w czerwcu 1997 r., składa się z rezolucji Rady Europejskiej oraz dwóch rozporządzeń. Rezolucja nie ma charakteru dokumentu wiążącego prawnie, zobowiązuje jedynie państwa do wdrażania procesu nadzoru budżetowego. Pierwsze ze wspomnianych rozporządzeń ma charakter zapobiegawczy: państwa strefy euro są zobowiązane do przedstawiania programów stabilności, kraje objęte derogacją mają zaś obowiązek przygotowania programów konwergencji. Drugie rozporządzenie ma charakter naprawczy: zawiera szczegółowe wyjaśnienia dotyczące procedur, które należy zastosować w wypadku nadmiernego deficytu, możliwych powodów zaistnienia takiej nierównowagi, sankcji oraz działań dyscyplinujących (zob. [Tendera-Właszczuk 2014, s. 66-67]).

Wyniki kolejnego raportu napawały już optymizmem, państwa członkowskie UE wykazały się wysokim poziomem determinacji w osiągnięciu wymaganego poziomu wskaźników (stabilności cen, stóp procentowych oraz stabilności fiskalnej) $\mathrm{i}$ wiele $\mathrm{z}$ nich spełniło wymagane warunki lub znacznie zbliżyło się do tego celu [Convergence... 1998]. Pozytywne wyniki konwergencji umożliwiły 11 państwom utworzenie 1 stycznia 1999 r. strefy euro [Kołodziejczyk 2000, s. 110-112].

W późniejszych latach do strefy euro przystąpiły kolejne państwa, które w większości wypadków całkowicie spełniły kryteria konwergencji, inne osiągnęły graniczne wartości wymaganego wskaźnika (Cypr oraz Malta przyjęły euro w 2008 r. z długiem publicznym wynoszącym odpowiednio: 61,5\% PKB oraz 65,9\% PKB) bądź pomimo dalszego przekraczania wartości referencyjnej wykazały znaczny postęp w zmniejszaniu nierównowagi (dług publiczny Grecji w 2001 r. wyniósł 103,7\% PKB, ale w ciągu pięciu lat zmniejszył się łącznie o 8,1 pkt proc.).

Od 2001 r. państwa członkowskie strefy euro ponownie zaczęły zwiększać deficyty budżetowe: początkowo były to Portugalia, Włochy oraz Grecja, w kolejnych latach Niemcy oraz Francja. Pomimo przyjęcia paktu oraz deklaracji politycznych Komisja i Rada nie mogły zastosować działań korygujących w tym zakresie. Okazało się, że nie było możliwości, aby zmusić państwa do przestrzegania dyscypliny budżetowej [Tendera-Właszczuk 2014, s. 67-68].

Przez kilka pierwszych lat funkcjonowania strefę euro można było uznać za sukces UE. Państwa, które przyjęły wspólną walutę, osiągały satysfakcjonujące wyniki makroekonomiczne, euro zaś w relatywnie krótkim czasie stało się drugą walutą świata. Kryzys gospodarczy zachwiał stabilnością wspólnego obszaru walutowego. Przez kolejne lata po wybuchu kryzysu kilka państw generowało 
nadmierny deficyt finansów publicznych, co przełożyło się na zwiększenie długu publicznego, który przekroczył próg $60 \%$ PKB. W takim ujęciu kryzys w UE ma charakter kryzysu zadłużeniowego, wywołanego nieprawidłowym zarządzaniem finansami publicznymi [Tendera-Właszczuk 2014, s. 68].

$\mathrm{Z}$ analizy raportów konwergencji oraz dostępnej literatury wynika jednoznacznie, że UE nie posiadała mechanizmów instytucjonalnych, które mogłyby uchronić ją przed kryzysem zadłużenia. W wyniku pojawiających się problemów przygotowano kolejną reformę zarządzania gospodarczego w Unii. Efektem prac było pięć rozporządzeń i jedna dyrektywa, tzw. sześciopak, przyjęte w celu wzmocnienia koordynacji polityki gospodarczej w państwach UE. Przepisy te weszły w życie 13 grudnia 2011 r. Ich zasadniczą rolą było wzmocnienie postanowień paktu stabilności i wzrostu w odniesieniu do stabilności budżetowej. Wprowadziły one możliwość uruchomienia procedury przeciwdziałania nadmiernemu deficytowi na podstawie kryterium długu publicznego, w wypadku gdy wartość ta przez dłuższy czas nie zbliża się do poziomu referencyjnego. Zalecenie lub wniosek Komisji odnośnie do sankcji w ramach procedury dotyczącej nadmiernego deficytu uznaje się za przyjęty, jeśli Rada nie odrzuci go większością kwalifikowaną (zob. [Tendera-Właszczuk 2014, s. 84-87]).

Oprócz paktu stabilności i wzrostu oraz procedury dotyczącej nadmiernego deficytu, które mają charakter narzędzi ex post, dodatkowym instrumentem koordynacji polityki ekonomicznej w państwach członkowskich jest tzw. semestr europejski, który wszedł w życie w 2011 r. Jest on narzędziem o charakterze ex ante i polega na analizie projektów budżetów państw członkowskich Unii przed ich zatwierdzeniem i przedstawieniu ich na forum. Pozwala to na uniknięcie podejmowania przez narodowe parlamenty decyzji, które mogą mieć wpływ na zwiększenie zadłużenia w zakresie finansów publicznych [Baran 2013, s. 150]. Jak zauważa H. Tendera-Właszczuk [2014, s. 93], wprowadzenie semestru europejskiego wiąże się z dość dużą ingerencją w suwerenność państw członkowskich w zakresie prowadzenia polityki budżetowej. Może to być istotny krok w kierunku utworzenia unii fiskalnej.

Wprowadzenie semestru europejskiego, wzmocnienie roli paktu stabilności i wzrostu oraz procedury dotyczącej nadmiernego deficytu przełożyły się na ograniczenie liczby państw, w których stwierdzono nierównowagę budżetową. W 2010 r. procedurą objęto 20 państw UE, w tym 13 państw strefy euro. Na początku 2014 r. procedura dotycząca nadmiernego deficytu była stosowana w 17 państwach Unii, z czego 12 należało do strefy euro. W maju 2016 r. Komisja prowadziła procedurę już tylko wobec sześciu państw UE, z czego cztery posiadały wspólną walutę [Tendera-Właszczuk 2014, s. 90-91].

Kolejny dokument mający na celu wzmocnienie koordynacji polityki budżetowej wszedł w życie z początkiem 2013 r. Traktat o stabilności, koordynacji 
i zarządzaniu, zwany potocznie paktem fiskalnym, jest umową międzynarodową, przyjętą przez 25 z 27 państw członkowskich UE. Pakt fiskalny oraz „sześciopak” funkcjonują równolegle, niektóre zapisy paktu fiskalnego są powieleniem postanowień, które weszły w życie w grudniu 2011 r., inne z kolei są bardziej rygorystyczne [Kotliński 2013, s. 201-217].

30 marca 2013 r. weszły w życie jeszcze dwa rozporządzenia Rady i Parlamentu Europejskiego, zwane dwupakiem. Ich rolą było dalsze wzmacnianie integracji i konwergencji gospodarczej państw strefy euro. Pierwsze rozporządzenie odnosi się do państw strefy euro objętych procedurą dotyczącą nadmiernego deficytu, drugie zaś dotyczy zasad wzmocnionego nadzoru w państwach członkowskich borykających się z trudnościami w utrzymaniu stabilności finansowej, korzystających z pomocy finansowej oraz w tych państwach, które kończą udział w programie pomocy finansowej [Baran 2013, s. 143-160].

Ze względu na brak unii fiskalnej w strefie euro oraz brak wspólnego budżetu mogącego pełnić funkcję stabilizacyjną (jak w wypadku budżetów krajowych) wprowadzono działania doraźne. Problemy Grecji zmusiły inne państwa do udzielenia jej wsparcia $w$ formie pożyczek bilateralnych oraz do wprowadzenia przez Unię oraz Międzynarodowy Fundusz Walutowy specjalnego pakietu fiskalnego. Rada Ecofin 9 maja 2010 r. podjęła decyzję o utworzeniu Europejskiego Instrumentu Stabilności Finansowej oraz Europejskiego Mechanizmu Stabilności Finansowej, które miały na celu utrzymywanie stabilności finansowej państw strefy euro znajdujących się w trudnej sytuacji finansowej. Zastosowanie tymczasowych rozwiązań przyczyniło się do sformułowania propozycji, a następnie realizacji planu utworzenia stabilnego mechanizmu. Zakładano utworzenie Europejskiego Funduszu Walutowego na wzór Międzynarodowego Funduszu Walutowego, który wspierałby państwa silnie zadłużone i gwarantował wewnętrzną stabilność unii walutowej (zob. [Mitręga-Niestrój 2014, s. 112-128]).

Kolejnym działaniem podjętym w celu stabilizacji sytuacji finansowej w Unii było rozwiązanie kwestii pożyczkodawcy ostatniej instancji. We wspomnianym trójkącie niespójności również poruszono ten problem. Co do zasady, art. 123 Traktatu o funkcjonowaniu UE zakazuje m.in. EBC i krajowym bankom centralnym udzielania pożyczek na pokrycie deficytu oraz nabywania bezpośrednio od zadłużonych krajów emitowanych przez nie papierów dłużnych. Korzystanie z pomocy pożyczkodawcy ostatniej szansy zostało więc ograniczone i nie jest możliwe wspieranie podmiotów mających problemy z płynnością finansową, zarówno jeśli chodzi o poszczególne banki, jak i cały sektor bankowy lub rządy. Ze względu na bariery traktatowe wprowadzono program skupu obligacji skarbowych (SMP), ograniczający interwencję EBC do działań na rynku wtórnym (zob. [Mitręga-Niestrój 2014, s. 128-133]). 


\section{Podsumowanie}

Zdaniem prominentnych europejskich polityków [Van Rompuy 2012, s. 1-7] oraz wielu specjalistów [Marzinotto, Sapir i Wolff 2011, s. 1; Shelburne 2012, s. 11; Veron 2012, s. 1] utworzenie unii fiskalnej istotnie wpłynęłoby na ustabilizowanie sytuacji budżetowej państw członkowskich UE oraz w szczególności strefy euro. Wprowadzenie drugiego, obok unii monetarnej, mechanizmu ujednolicającego zasady stosowania suwerennego dotychczas narzędzia polityki gospodarczej wymagałoby aprobaty zarówno przedstawicieli władz krajowych państw członkowskich, jak i ich obywateli [Dyba i Malec 2011, s. 167-168; Albiński 2014, s. 247-248].

Zdaniem specjalistów [de Grauwe i Moesen 2009, s. 1-4] kolejnym krokiem w tworzeniu unii fiskalnej powinno być wprowadzenie wspólnych obligacji lub mechanizmu pozwalającego na wykup i spłatę zadłużenia. W bardziej zaawansowanych propozycjach unii postuluje się utworzenie budżetu, odpowiadającego budżetom krajowym, oraz odpowiednika krajowego ministerstwa ds. finansów, odpowiedzialnego za pozyskiwanie dochodów i dysponowanie nimi [Marzinotto, Sapir i Wolff 2011, s. 4-5].

W kwestii uwspólnotowienia długu należy zwrócić uwagę na rodzaj wspólnych gwarantowanych papierów dłużnych, proponowane są m.in.: euroobligacje, obligacje czerwone i niebieskie, fundusz spłaty zadłużenia i obligacje projektowe. Zasadniczy problem z wprowadzeniem takiej formy unii fiskalnej wiąże się ze wspomnianą pokusą nadużycia, a więc nadużywaniem przez państwa o niskim ratingu gwarancji państw o wysokiej wiarygodności.

Najbardziej zaawansowaną formą unii fiskalnej są euroobligacje, dające gwarancję państw wiarygodnych słabszym gospodarkom. Dzięki temu państwa o niskim ratingu, korzystając na ogólnej wiarygodności unii, mają większe możliwości realizacji potrzeb pożyczkowych oraz obniżenia kosztów obsługi długu, co pozwala na szybsze wyjście z nierównowagi budżetowej. Obligacje projektowe są z kolei związane z wykonaniem konkretnych działań inwestycyjnych i wyłącznie w tym celu byłyby tworzone [Götz 2012, s. 94-99].

Ciekawa jest także propozycja dotycząca obligacji czerwonych i niebieskich, którą opracowano w dwóch wersjach. W opcji zaproponowanej przez brukselski think tank Bruegel zakłada się uwspólnotowienie długu poniżej 60\% PKB (obligacje niebieskie), potrzeby pożyczkowe powyżej tego poziomu (obligacje czerwone - mniej bezpieczne) byłyby zaś finansowane z krajowych papierów dłużnych [Delpla i von Weizsäcker 2011, s. 1-6]. Zastosowanie takich rozwiązań zagwarantowałoby standaryzację obligacji i jednocześnie odzwierciedlałoby kondycję gospodarczą zadłużonego państwa. Z taką konstrukcją wiąże się jednak ryzyko 
niewystąpienia impulsów dyscyplinujących. Zwiększa się także ryzyko, które muszą podjąć państwa gwarantujące wypłacalność.

W drugiej wersji, zaproponowanej przez niemiecką radę doradców ekonomicznych [Bofinger i in. 2011], uwspólnotowieniu miałyby podlegać obligacje powyżej 60\% PKB (obligacje czerwone). Istotą tej koncepcji jest kontrolowanie niebezpiecznie dużego długu, grożącego wpadnięciem w spiralę zadłużenia i niewypłacalnością związaną z coraz wyższym oprocentowaniem wymuszanym przez rynki finansowe. Celem jest zatem uniknięcie paniki i spekulowania na wzroście rentowności obligacji zadłużonego kraju. Proponuje się także utworzenie specjalnego funduszu gwarantującego spłatę zadłużenia. Na taki rachunek miałyby trafiać zobowiązania powyżej progu $60 \%$ PKB, jego obsługa zagwarantowana byłaby zaś przez wszystkie państwa członkowskie.

W literaturze przedmiotu wspomina się również o możliwości wprowadzenia, obok unii fiskalnej, unii bankowej, której utworzenie jest jedną z istotnych propozycji dotyczących ustabilizowania strefy euro i usprawnienia jej funkcjonowania [Munchau 2012; Asmussen 2013; Polański 2013, s. 215-224]. Twórcy tych propozycji zakładają, że unia bankowa będzie ograniczać sieć powiązań pomiędzy bankami a finansami publicznymi.

O ile pakt stabilności i wzrostu oraz pakt fiskalny, a także wprowadzone elementy unii bankowej [Szyszko 2015, s. 84-98; Zaleska 2015, s. 5-32]: Jednolity mechanizm nadzorczy [Przybylska-Kapuścińska i Skopowski 2015, s. 60-85] oraz Jednolity mechanizm restrukturyzacji i uporządkowanej likwidacji [Koleśnik 2015, s. 99-123]), to rozwiązania już stosowane, o tyle unia fiskalna pozostaje na razie tylko propozycją.

Z przedstawionych rozważań wynika, że nie jest możliwe funkcjonowanie stabilnej unii walutowej bez federalizmu fiskalnego. Działania podejmowane w warunkach kryzysu stały się potwierdzeniem tego, że problemy ze stabilnością finansową państw istotnie wpłynęły na możliwość pogłębienia współpracy w ramach unii fiskalnej. Co więcej, wiele takich rozwiązań instytucjonalnych, ukierunkowanych na federalizm fiskalny, zostało wprowadzonych w życie. Można się spodziewać, że kiedyś rozwiązania te będą stanowić podstawę unii fiskalnej w ramach UGiW. Przedłużający się kryzys może jednak wywołać falę ruchów antyintegracyjnych.

\section{Literatura}

Albiński P. [2014], Zakończenie - wnioski [w:] Kryzys a polityka stabilizacyjna w Unii Europejskiej, red. P. Albiński, Szkoła Główna Handlowa w Warszawie - Oficyna Wydawnicza, Warszawa. 
Asmussen J. [2013], Building Banking Union, London, https://www.ecb.europa.eu/press/ key/date/2013/html/sp130709.en.html (data dostępu: 20.02.2017).

Bagus P. [2010], The Tragedy of the Euro, Ludwig von Mises Institute, Auburn, Alabama. Balassa B. [1961], The Theory of Economic Integration, George Allen \& Unwin, London.

Baran B. [2013], Proces wzmacniania zarzqdzania gospodarczego w UE a niezależność krajowej polityki budżetowej [w:] Perspektywy integracji gospodarczej $i$ walutowej w Unii Europejskiej w czasach kryzysu, red. K. Opolski, J. Górski, Wydział Nauk Ekonomicznych Uniwersytetu Warszawskiego, Warszawa.

Biegun K. [2003], Kryteria optymalnego obszaru walutowego w rozszerzonej Unii Europejskiej, http://www.konferencja.edu.pl/ref8/pdf/pl/Biegun-Wroclaw.pdf (data dostępu: 20.03.2017).

Bofinger P., Feld L., Franz W., Schmidt C., Weder di Mauro B. [2011], A European Redemption Pact, VOX, CEPR's Policy Portal, http://voxeu.org/article/european-redemption-pact (data dostępu: 20.02.2017).

Convergence Report: Report Required by Article 109j of the Treaty Establishing the European Community [1998], European Monetary Institute, Frankfurt am Main, https:// www.ecb.europa.eu/pub/pdf/conrep/cr1998en.pdf?0575a6af6354ed9ed2f74e3e45a1cf99 (data dostępu: 20.02.2017).

Dadush U., Wyne Z., Ali S. [2012], Club Med and the Sun Belt: Lessons from Adjustment within a Monetary Union, http://www.voxeu.org/article/club-med-and-sun-beltlessons-adjustment-within-monetary-union (data dostępu: 20.02.2017).

Delpla J., Weizsäcker J. von [2011], Eurobonds: The Blue Bond Concept and Its Implications, Bruegel Policy Contribution, nr 2, http://bruegel.org/wp-content/uploads/imported/publications/110322_pc_blue_bonds.pdf (data dostępu: 20.02.2017).

Dyba A., Malec P. [2011], Stabilność finansów publicznych państw Unii Europejskiej w obliczu kryzysu zadłużeniowego, red. H. Tendera-Właszczuk, Fundacja Uniwersytetu Ekonomicznego w Krakowie, Kraków.

The European Stability Mechanism and the Case for an Irish Referendum [2011], People's Movement, Dublin, http://www.people.ie/eu/esmref2.pdf (data dostępu: 20.02.2017).

Gajda-Kantorowska M., Tarnawska K. [2009], Kontrowersje wokół roli Paktu stabilizacji $i$ wzrostu jako instrumentu koordynacji polityki gospodarczej w ramach Unii Gospodarczo-Walutowej [w:] Studia i Prace Wydziału Ekonomii i Stosunków Międzynarodowych, nr 2, Wydawnictwo Uniwersytetu Ekonomicznego w Krakowie, Kraków.

Gajewski P. [2013], Kryzys w strefie euro. Przyczyny, przebieg i perspektywy jego rozwiqzania, Narodowy Bank Polski, Warszawa.

Götz M. [2012], Kryzys i przyszłość strefy euro, Difin, Warszawa.

Grauwe P. de [2003], Unia walutowa: funkcjonowanie $i$ wyzwania, PWE, Warszawa.

Grauwe P. de, Moesen W. [2009], Gains for All: A Proposal for a Common Eurobond, CEPS, https://www.ceps.eu/publications/gains-all-proposal-common-eurobond (data dostępu: 20.02.2017).

Kawalec M. [2014], Założenia teoretyczne a funkcjonowanie unii walutowej [w:] Kryzys Unii czy kryzys w Unii? Kierunki dyskusji nad przyszłościq integracji europejskiej, red. H. Tendera-Właszczuk, Difin, Warszawa.

Kawalec S., Pytlarczyk E. [2016], Paradoks euro. Jak wyjść z pułapki wspólnej waluty?, Wydawnictwo Poltext, Warszawa. 
Kenen P. [1969], The Theory of Optimum Currency Areas: An Eclectic View [w:] Monetary Problems of the International Economy, red. R.A. Mundell, A.K. Swoboda, The University of Chicago Press, Chicago-London.

Koleśnik J. [2015], Jednolity mechanizm restrukturyzacji i uporzqdkowanej likwidacji [w:] Europejska Unia Bankowa, red. M. Zaleska, Difin, Warszawa.

Kołodziejczyk K. [2000], Geneza wspólnotowej waluty euro, Wydawnictwo Naukowe Scholar, Warszawa.

Kotliński K. [2013], Zmiany w koordynacji polityki budżetowej Unii Europejskiej po 2010 roku [w:] Perspektywy integracji gospodarczej $i$ walutowej w Unii Europejskiej w czasach kryzysu, red. K. Opolski, J. Górski, Wydział Nauk Ekonomicznych Uniwersytetu Warszawskiego, Warszawa.

Marzinotto B., Sapir A., Wolff G.B. [2011], What Kind of Fiscal Unions?, Bruegel Policy Brief, nr 6, http://bruegel.org/wp-content/uploads/imported/publications/111124_ pb_2011-06__.pdf (data dostępu: 20.02.2017).

McKinnon R. [1963], Optimum Currency Areas, „The American Economic Review”, nr 53.

Mitręga-Niestrój K. [2014], Mechanizmy zarzq̨dzania kryzysem finansowym [w:] Zarzqdzanie gospodarcze $w$ strefie euro, red. J. Pietrucha, J. Żabińska, Difin, Warszawa.

Munchau W. [2012], Welcome Back - Again - to the Eurozone Crisis, „Financial Times”, 1 November.

Mundell R. [1961], A Theory of Optimum Currency Areas, ,The American Economic Review", vol. 51, nr 4.

Pielach M. [2012], Philippe Maystadt: Nie da się pogodzić unii monetarnej i suwerenności państwa w sprawach ekonomii, Obserwator Finansowy, https://www.obserwatorfinansowy.pl/forma/rotator/philippe-maystadt-nie-da-sie-pogodzic-unii-monetarnej-isuwerennosci-panstwa-w-sprawach-ekonomii/ (data dostępu: 20.02.2017).

Pisani-Ferry J. [2012], The Euro Crisis and the New Impossible Trinity, Bruegel Policy Contribution No 2012/01, http://bruegel.org/wp-content/uploads/imported/publications/pc_2012_01_.pdf (data dostępu: 20.02.2017).

Polański Z. [2014], Debata na temat kolejnych działań Unii Europejskiej [w:] Kryzys a polityka stabilizacyjna w Unii Europejskiej, red. P. Albiński, Szkoła Główna Handlowa w Warszawie - Oficyna Wydawnicza, Warszawa.

Progress towards Convergence 1996 [1996], European Monetary Institute, Frankfurt am Main, https://www.ecb.europa.eu/pub/pdf/conrep/cr1996en.pdf?cb6c941136belbc4938012a58c22c0d0 (data dostępu: 20.02.2017).

Przybylska-Kapuścińska W., Skopowski M. [2015], Wyzwania zwiąane z wdrożeniem jednolitego mechanizmu nadzoru [w:] Europejska Unia Bankowa, red. M. Zaleska, Difin, Warszawa.

Shelburne R.C. [2012], Restoring Stability to Europe, United Nations Economic Commission for Europe, Discussion Paper Series No 2012.3, Geneva, https://www.unece. org/fileadmin/DAM/oes/disc_papers/ECE_DP_2012-3.pdf (data dostępu: 20.02.2017).

Szyszko M. [2015], Polityka nadzorcza i pieniężna pod wspólnym dachem EBC [w:] Europejska Unia Bankowa, red. M. Zaleska, Difin, Warszawa.

Tendera-Właszczuk H. [2014], Działania stabilizacyjne $i$ antykryzysowe w Unii Europejskiej [w:] Kryzys Unii czy kryzys w Unii? Kierunki dyskusji nad przyszłościq integracji europejskiej, red. H. Tendera-Właszczuk, Difin, Warszawa. 
Tornell A., Westermann F. [2012], The Tragedy of the Commons at the European Central Bank and the Next Rescue, VOX, CEPR's Policy Portal, http://www.voxeu.org/article/ tragedy-commons-european-central-bank (data dostępu: 20.02.2017).

Van Rompuy H. [2012], Towards a Genuine Economic and Monetary Union: Report by President of the European Council Herman Van Rompuy, Brussels, https://www.consilium.europa.eu/media/21570/131201.pdf (data dostępu: 20.02.2017).

Veron N. [2012], The Challenges of Europe's Fourfold Union, Bruegel Policy Contribution, nr 13, http://bruegel.org/wp-content/uploads/imported/publications/pc_2012_13_ senate.pdf (data dostępu: 20.02.2017).

Zaleska M. [2015], Zintegrowane ramy finansowe - koncepcja i wyzwania [w:] Europejska Unia Bankowa, red. M. Zaleska, Difin, Warszawa.

\section{The Impact of the Financial Crisis on the Possibility of Introducing Fiscal Federalism in the Euro Area}

(Abstract)

The economic and monetary union is undergoing crisis, one triggered by both internal and external factors. The problems that arose as a result of macroeconomic shock brought the monetary union's structural flaws to the fore. The purpose of this article is to determine if a stable monetary union is possible without a fiscal union and how the financial crisis has affected the possibility of fiscal federalism in the euro area. The problem of the euro area was tackled in the context of the economic crisis and will highlight the main problems of the monetary union and the management of the financial crisis in the EU. An analysis of the institutional arrangements introduced as a result of emerging problems in achieving nominal convergence in the euro area and budgetary imbalances arising from the global financial crisis was also examined. These solutions can in the long term form the basis for the creation of a fiscal union within the euro area.

Keywords: the European Union, the euro zone, the monetary union, the fiscal union. 